\title{
Kidney histotexure and serum creatinine level in response to concurrent administration of alcohol and coffee in mice
}

\author{
MT Islam¹, MK Islam MZ Hossain and MA Wares² \\ Department of Physiology, Faculty of Veterinary Science, Bangladesh Agricultural \\ University, Mymensingh-2202, Bangladesh
}

\begin{abstract}
The effect of alcohol and coffee on renal function with pathological changes in kidney was determined in mice. Sixty Albino mice were randomly divided into six equal groups. The mice of group A were maintained as control and remaining five groups were used as treated groups. The mice of control group were supplied with normal mice pellets whereas other groups were supplied with same pellets in addition to $5 \%$ coffee (in drinking water), $10 \%$ coffee, $10 \%$ alcohol, $5 \%$ coffee plus $5 \%$ alcohol and $10 \%$ coffee plus $10 \%$ alcohol, for 90 days. The serum creatinine level was significantly $(\mathrm{P}<0.01)$ higher in groups supplied with alcohol. There was huge infiltration of reactive cells and mild haemorrhagic spots in kidney of mice that received 10\% coffee and 10\% alcohol, respectively. It is suggested that long use of high doses of alcohol and coffee impaired kidney function. (Bangl. vet. 2015. Vol. 32, No. 2, 42 - 47)
\end{abstract}

\section{Introduction}

Alcohol is a depressant psychoactive drug that reduces attention and reaction speed. It comes in many forms, including beer, wine and spirits. Beer is the third most consumed beverage following water and coffee, and is the oldest alcoholic beverage (Nelson, 2005).

Alcohol is popular throughout the world, but it has become a threat to people who consume alcohol regularly, as it causes serious diseases, predominantly cirrhosis, fatty liver and steatosis, which are considered the highest public health threats (Rao et al., 2004).

Coffee is a brewed beverage with a distinct aroma and flavour prepared from the roasted seeds (beans) of the Coffee tree (Coffea species), cultivated in over 70 countries. Green (unroasted) coffee is one of the most traded agricultural commodities in the world. Coffee is slightly acidic ( $\mathrm{pH} 5.0$ - 5.1) and has a stimulating effect on humans. It is one of the most-consumed beverages in the world (Villanueva et al., 2006). Findings are contradictory as to whether coffee has any health benefits, and results are similarly conflicting regarding potentially harmful effects. Variations in findings can

\footnotetext{
${ }^{1}$ Government Dairy and Cattle Development Farm, Rajabarihat, Rajshahi-6201, Bangladesh

${ }^{2}$ Department of Anatomy and Histology, Faculty of Veterinary Science, Bangladesh Agricultural University, Mymensingh-2202, Bangladesh

*Corresponding authors:- E-mail: k_islam88@yahoo.co.in
} 
be partially resolved by considering the method of preparation. In addition, variation in serving size could partially explain differences between beneficial or harmful effects of coffee consumption.

Coffee consumption is shown to have minimal impact on cancer development (Ames and Gold, 1998). Other studies suggest that coffee consumption reduces the risk of Alzheimer's disease, Parkinson's disease, heart disease, diabetes mellitus type 2, cirrhosis of the liver (Klatsky et al., 2006), and gout (Choi et al., 2007). Most of coffee's beneficial effects against type 2 diabetes are due to decaffeinated coffee (Pereira et al., 2006). Additionally, coffee drinking reduces the risk of Parkinson's disease (Webster, 2000), gallstone disease (Leitzmann, 1999), cardiovascular disease (Koizumi et al., 2011), dental plaque formation (Touger-Decker and van Loveren, 2003), high blood pressure (Matsuura et al., 2012). On the other hand, it increases the risk of cancer (Ames and Gold, 1998), raising levels of low-density lipoprotein or LDL (Ricketts et al., 2007), iron deficiency anaemia in mothers and infants (Muñoz et al., 1988). There are reports of lower blood levels of hepatocellular enzymes in coffee drinkers (Zivković, 2000). Because elevated levels of these enzymes are thought to be a sensitive marker of acute or subacute liver damage, these reports offer indirect support for possible protection by coffee. It is unclear whether the inverse relation is associated with caffeine or some other ingredient. The question of whether the inverse relation is specific for alcoholic liver disease is also unresolved. This study was undertaken to evaluate the status of tissue-texture of kidney and serum creatinine of mice following coffee and alcohol administration.

\section{Materials and Methods}

Sixty, two-months-old male Swiss Albino mice (Mus musculus) with an average body weight of $20-23 g$ were randomly divided into six equal groups. All groups were supplied with standard mice pellets (4g each/day) and fresh drinking water was given ad libitum throughout the 90-day period. Group A was kept as control and fed with normal mice pellets only. Mice of group B, C, D, E and F were supplied with 5\% coffee, $10 \%$ coffee, $10 \%$ alcohol, $5 \%$ alcohol $+5 \%$ coffee, $10 \%$ alcohol $+10 \%$ coffee, respectively. At the end of the study, mice were sacrificed for blood and kidney tissue collection. Blood was then used for serum collection and kidney tissues were fixed in $10 \%$ buffered formalin for subsequent histopathology.

\section{Serum analysis}

The clear serum was used for the estimation of serum creatinine by the auto analyzer apparatus (Reflotron Plus, Roche, Germany) using commercially available Reflotron kits (Roche Diagnostics, Germany). The principle of the test was based on the method described by Peake and Whiting (2006). Reflotron, is a solid phase reagent technology capable of measuring a wide range of analytes on whole blood, plasma or serum samples and the results show good concordance with conventional wet chemistry methods (Ahmad et al., 2011). 
Histopathology: This was done according to the standard procedure (Ahmad et al., 2011). In brief, after blood collection, the mice were sacrificed by cervical dislocation. Their kidneys were washed gently in normal saline and their fresh weight was recorded. The kidneys were fixed in $10 \%$ buffered formalin (NBF) for $24 \mathrm{~h}$ and rinsed with $70 \%$ ethanol, dehydrated in serial dilutions of ethanol before embedding in paraffin wax. Paraffin blocks of the tissues were sectioned at 5-6 $\mathrm{mm}$ thickness in a rotary microtome. Sections were processed for staining with haematoxylin and eosin for histopathological details. Photographs of the sections were taken at different magnifications in a Nikon Eclipse E600 Binocular Microscope fitted with Nikon Digital Camera model DXM1200F, Japan.

\section{Results and Discussion}

Serum creatinine: The effects of alcohol and coffee on serum creatinine are presented in Table 1. The concentration of creatinine increased significantly $(\mathrm{P}<0.05)$ in mice supplied with $10 \%$ alcohol but not with coffee. This finding is similar to the study of Singaravelu et al. (2013), who found elevated serum creatinine after alcohol consumption in apparently healthy human beings. When mice were supplied with $10 \%$ coffee along with the same quantity of alcohol, the creatinine concentration did not increase. This suggests that the effect of alcohol might have been counteracted by the coffee.

Table 1. Effects of alcohol and coffee administration on serum creatinine $(\mathrm{mg} / \mathrm{dL})$ in mice

\begin{tabular}{l|cc}
\hline \multirow{2}{*}{\multicolumn{1}{c|}{ Groups }} & \multicolumn{2}{c}{ Serum creatinine $(\mathrm{mg} / \mathrm{dL})$} \\
\cline { 2 - 3 } & Pre-Treatment & Post-Treatment \\
\hline A (Control) & $0.63 \pm 0.12$ & $0.70 \pm 0.11^{\mathrm{NS}}$ \\
B (5\% Coffee) & $0.57 \pm 0.12$ & $0.60 \pm 0.14^{\mathrm{NS}}$ \\
C (10\% Coffee) & $0.45 \pm 0.11$ & $0.50 \pm 0.14^{\mathrm{NS}}$ \\
D (10\% Alcohol) & $0.42 \pm 0.16$ & $0.73 \pm 0.12^{*}$ \\
E (5\% Coffee+ 5\% Alcohol) & $0.56 \pm 0.13$ & $0.60 \pm 0.16^{\mathrm{NS}}$ \\
F (10\% Coffee+ 10\% Alcohol) & $0.50 \pm 0.11$ & $0.52 \pm 0.16^{\mathrm{NS}}$ \\
\hline
\end{tabular}

Data are shown as mean \pm SD of 5 samples per group *Significant at $5 \%$ level $(P<0.05)$, NS Non significant

The role of coffee is supported by the work of Kim et al. (2013) and Jane and Balz (2006) where middle-aged and elderly women showed decrease in the renal impairment after coffee drinking. The mice that received alcohol or coffee either separately or in combination at 5\% did not reveal significant change in their serum creatinine.

Fig. 1-6 shows renal histological features of different groups of mice that received various levels of alcohol and/or coffee. There was no lesion in renal parenchyma, except in mice receiving either alcohol or coffee at $10 \%$ level where there was infiltration of reactive cells and mild haemorrhage (Fig. 4 and Fig. 5, respectively). 


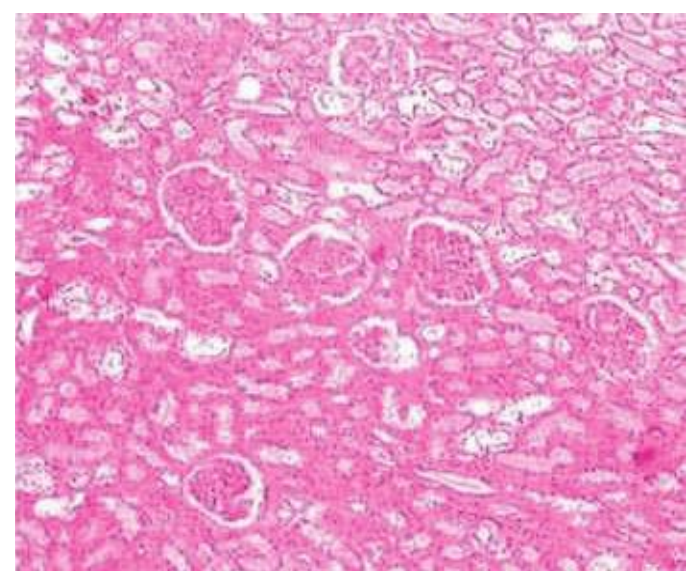

Fig. 1. Micrograph of kidney from group A having normal appearance (H \& E, X 200)

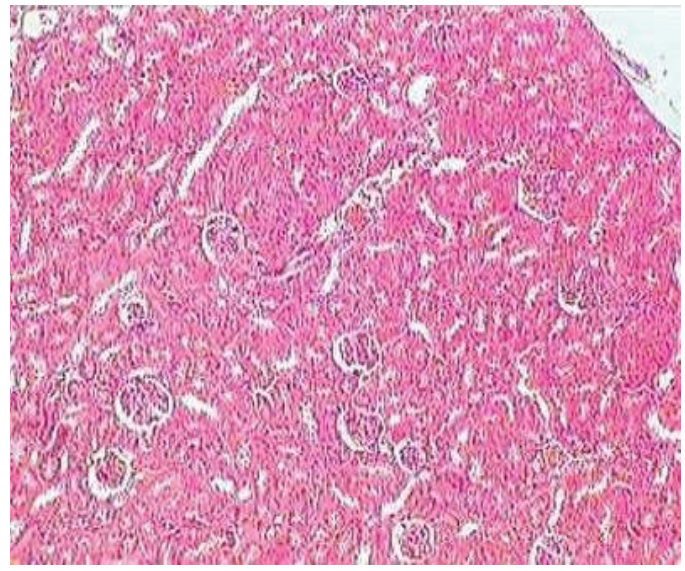

Fig. 3. Micrograph of kidney from group $\mathrm{C}$ having mild infiltration of inflammatory cells $(\mathrm{H}$ \& E, X200)

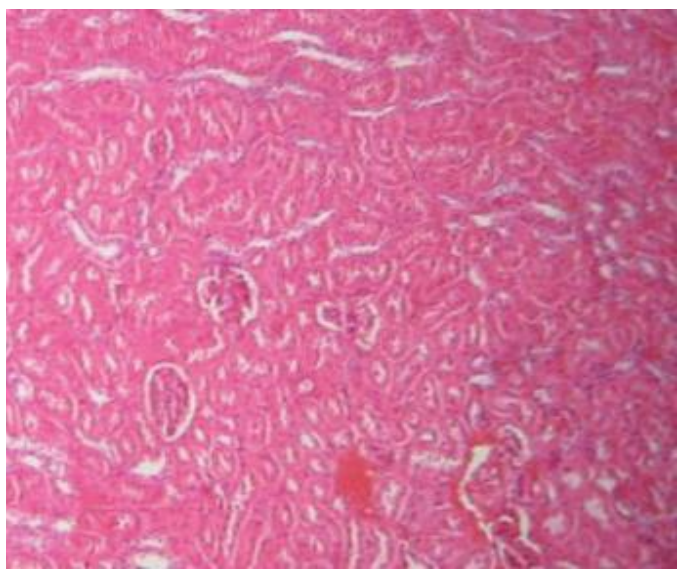

Fig. 5. Micrograph of kidney from group E having almost normal parenchyma (H \& E, X 200)

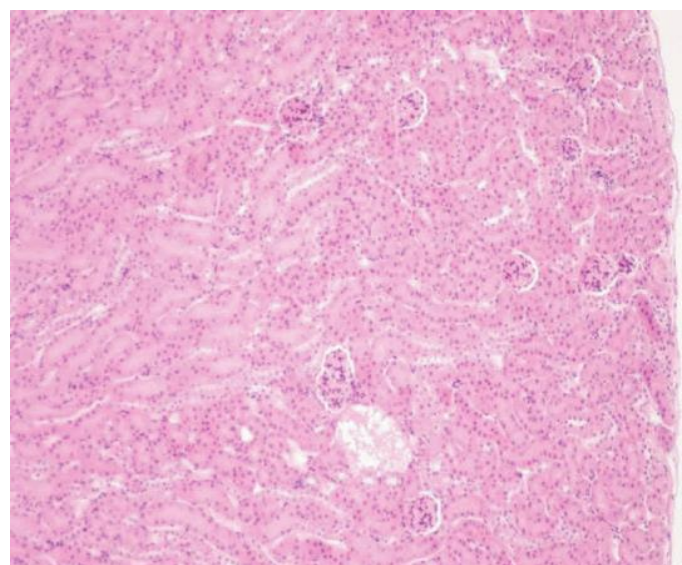

Fig. 2. Micrograph of kidney from group B having normal renal parenchyma (H \&E, X 200)

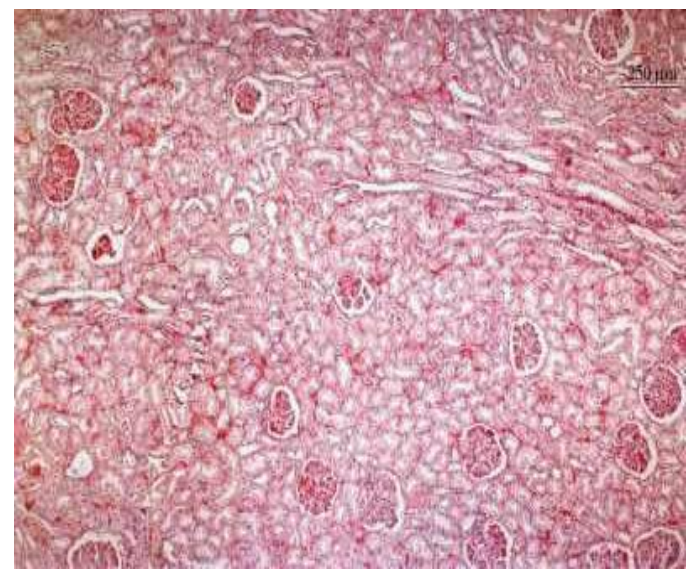

Fig. 4. Micrograph of kidney from group D having mild haemorrhage (H \& E, X 200)

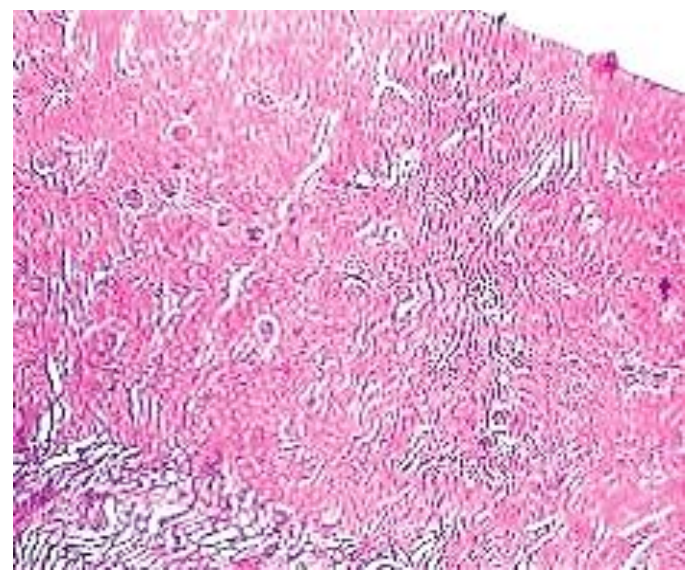

Fig. 6. Micrograph of kidney from group F having almost normal parenchyma (H \& E, X 100) 
This result indicates that higher consumption of alcohol or coffee might impair renal function. The results are consistent with the previous work of Latchoumycandane et al., (2014); David et al., (1977); Epstein, (1997) in which renal damage with an inflammatory cell infiltrate and oxidative damage of kidney lipids and proteins after long term ethanol ingestion has been reported.

\section{Conclusions}

The present work reveals that high concentrations of alcohol and coffee when taken in larger amount cause impaired renal function in mice, with a rise in serum creatinine and disruption of normal renal histo-architexture. Continual taking of high doses of alcohol and coffee can be detrimental to kidney function.

\section{Acknowledgement}

The authors are grateful to National Agricultural Technology Project (NATP), Department of Livestock Services (DLS), Dhaka, Bangladesh for providing financial assistance.

\section{Dedication}

The work is dedicated to Late Md. Zubaed Hossain, one of the authors of this article, who gave the primary shape to this article for its submission to the journal.

\section{References}

Ahmad M, Elnakady Y, Farooq M, Wadaan M 2011: Lithium Induced Toxicity in Rats: Blood Serum Chemistry, Antioxidative Enzymes in Red Blood Cells and Histopathological Studies. Biological and Pharmaceutical Bulletin 34 272-277.

Ames BN, Gold LS 1998: The causes and prevention of cancer: the role of environment. Biotherapy 11 205-220.

Choi HK, Willett W, Curhan G 2007: Coffee consumption and risk of incident gout in men: A prospective study. Arthritis and Rheumatism 56 2049-2055.

David H, Thiel V, Judith S. Gavaler JM, Little LR 1977: Alcohol: Its effect on the kidney. Metabolism 26 857-866.

Epstein M 1997: Alcohol's impact on kidney function, Alcohol Health Research World 21 84-92.

Jane VH, Balz F 2006: Coffee and Health: A Review of Recent Human Research. Critical Reviews in Food Science and Nutrition 46 101-123

Kim BH, Park YS, Noh HM, Sung JS, Lee JK 2013: Association between Coffee Consumption and Renal Impairment in Korean Women with and without Diabetes: Analysis of the Fourth Korea National Health and Nutrition Examination Survey. Korean Journal of Farm Medicine 34 265-271 
Klatsky AL, Morton C, Udaltsova, Natalia; Friedman, Gary D 2006: Coffee, cirrhosis, and transaminase enzymes. Archives of Internal Medicine 166 1190-1195.

Koizumi A, Mineharu Y, Wada Y, Iso H 2011: Coffee, green tea, black tea and oolong tea consumption and risk of mortality from cardiovascular disease in Japanese men and women. Journal of Epidemiology and Community Health 65 230-240.

Latchoumycandane C, Nagy LE, McIntyrea TM 2014: Chronic Ethanol Ingestion Induces Oxidative Kidney Injury through Taurine-inhibitable Inflammation. Free Radical Biology and Medicine 69 403-416.

Leitzmann MF 1999: A prospective study of coffee consumption and the risk of symptomatic gallstone disease in men. Journal of the American Medical Association 281 2106-2112.

Matsuura H, Mure K, Nishio N, Kitano N, Nagai N, Takeshita T 2012: Relationship between coffee consumption and prevalence of metabolic syndrome among Japanese civil servants. Journal of Epidemiology 22 160-166.

Muñoz LM, Lönnerdal B, Keen CL, Dewey KG 1988: Coffee consumption as a factor in iron deficiency anemia among pregnant women and their infants in Costa Rica. American Journal of Clinical Nutrition 48 645-651.

Nelson M 2005: The Barbarian's Beverage: A History of Beer in Ancient Europe. Abingdon, Oxon: Routledge ISBN 0-415-31121-7.

Peake M, Whiting M 2006: Measurement of Serum Creatinine - Current Status and Future Goals. The Clinical Biochemist Reviews 27 173-184.

Pereira MA, Parker ED, Folsom, Aaron R 2006: Coffee consumption and risk of type 2 diabetes mellitus: An 11-year prospective study of 28812 postmenopausal women. Archives of Internal Medicine 166 1311-1316.

Rao RK, Seth A, Sheth P 2004: Recent advances in alcoholic liver disease I. Role of intestinal permeability and endotoxemia in alcoholic liver disease. American Journal of Physiology 286 881-884.

Ricketts ML, Boekschoten MV, Kreeft AJ, Hooiveld GJ, Moen CJ, Müller M, Frants RR, Kasanmoentalib S, Post SM, Princen HM, Porter JG, Katan MB, Hofker MH, Moore DD 2007: The cholesterol-raising factor from coffee beans, cafestol, as an agonist ligand for the farnesoid and pregnane $\mathrm{X}$ receptors. Molecular Endocrinology 21 1603-1616.

Singaravelu S, Sheethal KC , Shanthakumari 2013: Serum Levels of Renal Parameters in Light, Moderate and Heavy Drinkers: A Relation to Pattern of Alcohol Intake, International Journal of Contemporary Medicine 1 119-122

Touger-Decker R, van Loveren C 2003: Sugars and dental caries, American Journal of Clinical Nutrition 78 881-892.

Villanueva, CM, Cantor KP, King WD, Jaakkola JJK, Cordier S, Lynch CF, Porru S, Kogevinas M 2006: Total and specific fluid consumption as determinants of bladder cancer risk. International Journal of Cancer 118 2040-2047.

Webster RG 2000: Association of Coffee and Caffeine Intake with the Risk of Parkinson Disease. Journal of the American Medical Association 283 2674-2679

Zivković R 2000: Coffee and health in the elderly. Acta Medica Croatica 54 33-36. 